\title{
Wędrujące pomniki w przestrzeni Słupska (przed II wojną światową i po niej)
}

\begin{abstract}
Zarys treści: W rozdziale są przedstawione Denkmale istniejące w Słupsku przed II wojną światową oraz pomniki, które wzniesiono na ich miejscu po 1945 roku. Zwrócono też uwagę na obiekty przedwojenne, które po wojnie zmieniły swoją pierwotną lokalizację (np. pomnik pamięci ofiar wojny francusko-pruskiej, rzeźba Upokorzony, fragmenty niemieckich nagrobków i żydowskich macew). Na przykładzie pomników został przedstawiony zarys powojennej polityki historycznej stosowanej wobec zastanego dziedzictwa kulturowego Ziem Zachodnich i Północnych. Przejawem tej polityki było niszczenie znaków obcej kultury lub jej ignorowanie i zmienianie semantyki. Zauważono, że istotną rolę w traktowaniu obcego dziedzictwa odegrał zwrot kulturowy dokonany po transformacji 1989 roku oraz zniesieniu cenzury w 1990 roku. Słupskie pomniki przedstawiono w kontekście teorii miejsc pamięci, kultury pamięci, polityki historycznej, historii w przestrzeni publicznej i zastanego „trudnego dziedzictwa”. Ich losy w mieście „o wymienionej krwi” ujawniają strategię odrzucania lub przyswajania obcego dziedzictwa, a jednocześnie skłaniają do refleksji nad przeszłością i przyszłością.
\end{abstract}

Słowa kluczowe: Słupsk, pomnik, teoria miejsc pamięci, polityka historyczna, trudne dziedzictwo.

\section{Wprowadzenie}

Słupsk i okolice miasta mają niezwykle interesującą historię. Na przełomie stuleci zamieszkiwali te tereny i kształtowali ich obraz Słowińcy, Kaszubi, Polacy, Niemcy, Żydzi i przedstawiciele innych nacji, np. Ukraińcy, którzy na Ziemi Słupskiej osiedlili się po II wojnie światowej. Zróżnicowanie etniczne wpływało na różnice konfesyjne, kulturowe i obyczajowe. Aktualnie gród nad Słupią cieszy się opinią ośrodka, w którym istnieje wiele profesjonalnych placówek kulturalnych i są w nim podejmowane różne inicjatywy lokalne oraz wykraczające poza granice regionu - można w tym miejscu wymienić np. organizowany od ponad pięćdziesięciu lat Festiwal Pianistyki Polskiej (odbywający się od roku 1967 wraz z towarzyszącą mu od 1974 roku Estradą Młodych), prężnie działające Muzeum Pomorza Środkowego (z oddziałami etnograficznymi w Klukach i w Swołowie), w którym można oglądać unikalną kolekcję dzieł Witkacego eksponowaną 
w najnowszym obiekcie tej instytucji - Białym Spichlerzu Sztuki, czy też Festiwal Muzyki Organowej i Kameralnej organizowany od 1983 roku (koncerty odbywają się w zabytkowym kościele św. Jacka w Słupsku). Działania te budują pozytywny obraz miasta otwartego na zmiany, ale i kultywującego tradycję i pielęgnującego zastane dziedzictwo kulturowe, chociaż - jak się okazuje po bliższym przyjrzeniu się tej problematyce - nie w pełni ${ }^{1}$.

\section{Tropem słupskich pomników}

Status współczesny - z pewnymi zastrzeżeniami, które zostaną sformułowane w szkicu - nie jest tożsamy z postawą, jaką zajmowali wobec historii tej ziemi jej pierwsi powojenni mieszkańcy. Tuż po wojnie, w roku 1945 stanowili oni mieszankę głównie trzech narodowości: ludności autochtonicznej, czyli Niemców, którzy nie opuścili miasta (ok. 30 tys.) oraz czerwonoarmistów i Polaków (Romanow 2001; Skóra 2021: 161). W latach następnych na tzw. ziemiach odzyskanych, w tym też w Słupsku zaczęli się osiedlać Ukraińcy (w dużym stopniu przesiedlani w ramach akcji „Wisła”), ludność z Wileńszczyzny, Wołynia, Ziemi Lwowskiej (tzw. repatrianci) oraz przedstawiciele innych mniejszości etnicznych (np. Cyganie).

Działania nowych osadników w dużym stopniu były ukierunkowane na eliminowanie z krajobrazu miasta wszelkich śladów niemieckości. Zachowania tego rodzaju były adekwatne do powojennej polityki historycznej stosowanej wobec zastanego dziedzictwa kulturowego Ziem Zachodnich i Północnych. Oczywistą rzeczą jest, że na ziemiach tych niszczono znaki obcej kultury lub - w najlepszym wypadku - ją ignorowano i zmieniano jej semantykę. Jednakże „w miastach o wymienionej krwi" (Lewicka 2012: 451-507) w wyniku strategii przyswajania obcego dziedzictwa, pomniki nie zawsze w pełni traciły swą ideową tożsamość. Zdarzało się, że wrastały w powojenny krajobraz miasta, choć na nowych zasadach - np. jako dzieło sztuki (w Słupsku takim exemplum jest Upokorzony), czy też element konstrukcyjny dla nowego pomnika (przykładem w Słupsku może być postument Otto von Bismarcka, na którym po wojnie stanął Henryk Sienkiewicz).

Dbałość o historię Słupska sprzed II wojny światowej jest zjawiskiem stosunkowo „młodym”, rozwijającym się żywiej dopiero na przestrzeni dwóch ostatnich dekad. Jest to proces kompatybilny z rozwojem badań dotyczących przywiązania

${ }^{1}$ Definicję prawną dziedzictwa kultury podał Jan Pruszyński (2001). Według niego jest to: „zasób rzeczy nieruchomych i ruchomych wraz ze związanymi z nim wartościami duchowymi, zjawiskami historycznymi i obyczajowymi uznawanymi za podstawę ochrony prawnej dla dobra konkretnego społeczeństwa i jego rozwoju oraz dla przekazania ich następnym pokoleniom, z uwagi na zrozumiałe i akceptowane wartości historyczne, patriotyczne, religijne, naukowe i artystyczne, mające znaczenie dla tożsamości i ciągłości rozwoju politycznego, społecznego i kulturalnego, dowodzenia prawd i upamiętniania wydarzeń historycznych, kultywowania poczucia piękna i wspólnoty cywilizacyjnej”. 
do miejsca (place attachment), identyfikacji z miejscem (place identity), czy też doświadczania miejsca (sense of place). Warto zauważyć, że badania oscylujące wokół tej problematyki są wynikiem zmian, jakie obserwuje się w kontekście globalizacji i unifikacji przestrzeni. Konsekwencją tych przeobrażeń jest zwiększona wrażliwość na miejsce, zwłaszcza gdy wokół wdziera się przytłaczająca jednostajność, architektoniczna i komercyjna uniformizacja, czy światowa monokultura. Reakcją na tego typu cywilizacyjne procesy jest pragnienie doświadczenia unikatowości miejsca, zachowania jego „lokalnego” lub „regionalnego” statusu, utrwalenia historii i tożsamości. Gdy patrzymy na konkretny obszar jak na coś, co konstytuuje ludzkie bycie w świecie i stanowi jego istotę, dochodzimy do wniosku, że miejsce ma kardynalne znaczenie w życiu człowieka. Jego relacja z miejscem (domem, wsią, miastem, regionem) - zgodnie z koncepcją M. Heideggera (Heidegger 1954/2007) - jest tym samym fundamentalną relacją egzystencjalną; każda próba rozerwania tej więzi rodzi z jednej strony wzrost niepokoju, z drugiej potrzebę przywrócenia stanu „normalnego”, pragnienie odtworzenia przeszłości, utrwalenia jej w pamięci² (Casey 1997; Lewicka 2012: 20; Assmann 2013).

W Słupsku działania ukierunkowane na przywrócenie pamięci o przedwojennych mieszkańcach miasta zainicjowała Isabel Sellheim. Urodziła się 26 września 1929 roku w Stolp im Pommern (w Słupsku), a w 1945 roku razem z rodziną musiała Stolp opuścić. W połowie lat 90 . już jako emerytka wróciła do miasta nad Słupią. Po powrocie zaangażowała się w działania kulturalne ${ }^{3}$ i poświęcone międzynarodowemu porozumieniu między obywatelami Europy: Polakami,

${ }^{2}$ Pojęcie pamięci przeszło $\mathrm{w}$ nauce długą ewolucję - począwszy „od obecności w przednowoczesnej kulturze mówionej, do roli interpretatora historii w postmodernizmie". W najnowszych badaniach historycznych pojęcie to występuje na trzech poziomach - po pierwsze: wiąże się z ujęciami socjologicznymi i antropologicznymi (w tym $\mathrm{z}$ historią społeczną); po drugie: dotyczy miejsc pamięci konstytuujących stosunek współczesnego człowieka do czasów minionych; po trzecie: odnosi się do pracy z przeszłością, „,czerpiąc z doświadczenia psychoanalizy, zawiera kategorie pamiętania i zapominania, dotyka np. zbrodni totalitarnych, traumy społecznej z nimi związanej” (Chwedoruk 2018: 73-74). Istotnym zagadnieniem w tym kontekście jest również „kultura pamięci”. Memory studies to obszar, który - podobnie jak sama pamięć - nurtuje badaczy reprezentujących różne dyscypliny naukowe. Zdaniem Astrid Erll (2020: 67), począwszy od lat 80 . XX wieku, gdy pojawiły się tzw. nowe kulturoznawcze badania pamięci, zaczęto ją postrzegać jako „ważne zjawisko transdyscyplinarne, którego funkcjonowania nie da się zrozumieć, badając je wyłącznie z jednej perspektywy". W związku z takim założeniem we współczesnych badaniach dotyczących pamięci obserwuje się tendencję ich interdyscyplinarnego ukierunkowania i zbliżenia studiów literaturoznawczych, historycznych, socjologicznych czy psychologicznych.

${ }^{3}$ Wraz z Muzeum Pomorza Środkowego organizowała wystawy poświęcone niemieckim artystom pochodzącym z okolic Słupska: Otto Priebemu, Gottfriedowi Brockmann, Günterowi Machemehl i Otto Kuskemu. 
Niemcami i Żydami. Za jej działania miasto nadało jej tytuł Honorowej Obywatelki Słupska, a w drugą rocznicę jej śmierci - 30 lipca 2020 roku na ścianie budynku Przedszkola Miejskiego nr 6 przy ul. Wandy umieszczono tablicę pamiątkową (w domu tym Isabel Sellheim przyszła na świat).

Dziełu podjętemu przez Isabel Sellheim sprzyjał niewątpliwie zwrot kulturowy, jaki się dokonał w Polsce po transformacji 1989 roku i zniesieniu cenzury w roku 1990 (Chwedoruk 2018: 146-153). Oddolne inicjatywy odzyskiwania utraconej pamięci, a taki charakter niewątpliwie miały działania Honorowej Obywatelki miasta nad Słupią, wpłynęły na zamianę pojęcia „obce dziedzictwo" na „nasze wspólne” i przyczyniły się do otwartego spojrzenia na dobra kultury, które ówcześni mieszkańcy miast i wsi Pomorskich odziedziczyli po ich poprzednikach - ludziach, którzy tzw. ziemie odzyskane zamieszkiwali przed II wojną światową. „Elementy” przeszłości zawsze są jej depozytariuszami, a w przestrzeni publicznej funkcjonują jako ,miejsca pamięci” tak w znaczeniu topograficznym, umiejscowionym fizycznie (Nora 1984: XIX-XXI; Szpociński 2008: 11-19), jak i metaforycznym, jako symbole i znaki odwołujące się do osób i zdarzeń historycznych (Szpociński 1983: 129-146; Szpociński 1989; Trojański 2018: 135-141). Zachowane przedmioty, nawet tzw. ,zabytki bez żadnej wartości” (np. fragmenty murów miejskich, bruki ulic, napisy) przemawiają do współczesnego odbiorcy, o czymś „opowiadają” i pełnią rolę „świadków” zdarzeń, które już się dokonały; jednocześnie stanowią fragment ,żywej historii” w jej aspekcie kulturowym, politycznym i społecznym (Assorodobraj-Kula 1963; Szpociński 2008: 11, 18).

Pamiątkowe tablice, obeliski czy pomniki, to świadectwa przeszłości i teraźniejszości, które należą do materialnego dziedzictwa kultury (Kobyliński 2011; Praczyk 2015). Wpływają również na kształtowanie przestrzeni miejskiej i są jej istotnymi ozdobnikami. Stanowią lepsze lub gorsze przykłady monumentalnej twórczości plastycznej na danym etapie rozwoju sztuki, ujawniają możliwości artystyczne ich autorów, a jednocześnie odzwierciedlają gusta zleceniodawców. Oprócz formy, równie ważne, a często najważniejsze jest przesłanie, czyli zawarta w nich treść i symbolika. Znaczenie pomników dla dziedzictwa miasta, regionu czy państwa potwierdza ich zaznaczanie na mapach, opisy w przewodnikach itp.

Pomniki - wznoszone lub burzone - zawsze są znakiem czasu i historii, ponieważ utrwalają zdarzenia, często tak tragiczne jak wojna (Machura 2011; Skóra 2021) oraz umożliwiają weryfikowanie istniejących tendencji społecznych i kulturowych. W przypadku Słupska, w którym żyją ludzie stanowiący pewnego rodzaju tygiel kulturowy, etniczny, wyznaniowy, mają one znaczenie szczególne - przypominają, że historia jest zmienna, że przynależność terytorialna i włodarze ziemi nie trwają wiecznie. Symbolem tych przemian - $i$ jednocześnie pewnego rodzaju ciągłości - widocznym w przestrzeni miasta jest np. pomnik Bogusława $\mathrm{X}$ - reprezentanta Gryfitów, średniowiecznych władców tych ziem, usytuowany przed Zamkiem Książąt Pomorskich. Z kolei znakiem czasów najnowszych może 
być pomnik upamiętniający postać urodzonego w Stolp Otto Freundlicha. Jest to rzeźba nazywana Otwarta głowa, znajdująca się w parku imienia tegoż artysty za słupskim ratuszem. Należy ona do grupy tzw. Europejskiej Drogi Pokoju realizującej ideę braterskiego pojednania stworzoną przez Otto Freundlicha i jego partnerkę Jeanne Kosnick-Kloss; projekt zakładał połączenie rzeźbami północy z południem i wschodu z zachodem Europy, jest rozumiany jako testament artystyczny Freundlicha ${ }^{4}$.

W niniejszym szkicu interesować mnie będą głównie pomniki, które istniały w krajobrazie miasta przed II wojną światową oraz te, które zastąpiły niemieckie Denkmale 5 po 1945 roku. Obok nich zwrócę uwagę również na nagrobki (a w zasadzie ich ocalone fragmenty), które są świadectwem obecności przedwojennych mieszkańców miasta (Niemców i Żydów) oraz dowodem pamięci o nich. Kryterium egzemplifikacyjnym będzie zatem zmienność - tak przywoływanych obiektów, jak i ich lokalizacji.

Przed II wojną światową miasto nad Słupią zamieszkiwali głównie Niemcy. Pomniki, które stawiali w Stolp im Pommern były związane z aktualnymi wówczas wydarzeniami i postaciami według nich godnymi upamiętnienia i uhonorowania. Biorąc pod uwagę przestrzenny układ miasta, obiekty te były lokowane w miejscach reprezentacyjnych i ogólnie dostępnych (Machura 2011; Foltyn 2021). Najważniejszym obszarem $\mathrm{w}$ przestrzeni zurbanizowanej są $\mathrm{z}$ reguły skwery w centralnych miejscach miasta i place przed ratuszem ${ }^{6}$. Na takim właśnie placu, zwanym początkowo Wollmarktem (Targiem Wełnianym), od roku 1888 do końca II wojny światowej - placem Heinricha von Stephana ${ }^{7}$, a obecnie placem Zwycięstwa, wzniesiono w Słupsku pierwszy pomnik. Było to w roku 1875. Monument stanął ku pamięci tych, którzy zginęli w czasie wojny francusko-pruskiej w latach 1870-71. Pomnik ozdobił miejsce, które po wybrukowaniu kostką

${ }^{4}$ Plany Otto Freundlicha pokrzyżował wybuch II wojny światowej, podczas której artysta został zamordowany w obozie na Majdanku. Po wojnie jego pomysł podchwycił prof. Leo Kornbrus. W trakcie realizacji projektu wspólnie z artystami z 12 krajów stworzył rzeźby w kilku państwach, m.in. w Niemczech, Holandii, Belgii i we Francji. Autorem słupskiej rzeźby jest profesor Jan Stanisław Wojciechowski, rzeźbiarz i teoretyk sztuki z Warszawy. Pomnik został odsłonięty w listopadzie 2007 roku.

${ }^{5}$ Niemieckie określenie Denkmal pochodzi od czasownika denken, który oznacza: „myśleć, „wyobrażać sobie” i ,pamiętać” oraz od rzeczownika Mal, który w języku polskim oznacza „znak” lub znamię”. Termin ten odpowiada polskiemu słowu ,pomnik” lub „monument”, które pochodzi od łacińskiego rzeczownika monumentum, a oznacza „pamiątka”, „znak pamięci” oraz czasownika moneo, które znaczy „napominać”, „opowiadać" (Kubalska-Sułkiewicz 1997: 322-323).

${ }^{6}$ Obecny ratusz jest trzecim z kolei, jaki zapisał się w historii miasta. Pierwsze dwa były ulokowane na terenie dzisiejszego Starego Rynku (Foltyn 2021).

${ }^{7}$ Heinrich von Stephan pochodził ze Stolp im Pommern i mieszkał w tym mieście, był ministrem poczty Rzeszy Niemieckiej i wynalazcą kartki pocztowej - pocztówki. 
pochodzącą ze Szwecji przestało pełnić funkcję targową , a zyskało status miejsca reprezentacyjnego.

Na tym właśnie placu Zwycięstwa, w roku 1910 z okazji 600-letniej rocznicy nadania grodowi nad Słupią praw miejskich, przed nowo wybudowanym ratuszem stanęła figura cesarza Wilhelma I (ryc. 1). Wydarzenie to jest interpretowane przez historyków jako punkt kulminacyjny w procesie organizacji przestrzennej miasta nad Słupią jeszcze przed I wojną światową (Schulz, Wolter 1984: 94-97). Jest to związane z historią tego terenu. W miejscu, na którym znajduje się teraźniejszy ratusz, do połowy XIX wieku był staw zwany Quebbe vor dem Neuen Tor. Żeby obszar ten zagospodarować, konieczne było osuszenie gruntu. Najlepszym rozwiązaniem wydawało się zasypanie bajorka. Przetarg ogłoszony przez Radę Miejską na wykonanie tego zadania wygrał nieznany z imienia mistrz piekarski, niejaki Wienandt. Zlecenie nie przyniosło mu jednak zysku, na jaki z pewnością liczył przystępując do przetargu. Wręcz przeciwnie, doprowadziło go niemal do bankructwa. Wienandt w ciągu niecałych trzech lat (począwszy od 1852 r.) rozkopał Górę św. Piotra, skąd wywiózł ponad 30 tys. furmanek piasku9 . Gdy w roku 1855 praca została ostatecznie przyjęta, powstał znany nam współcześnie słupski plac Zwycięstwa. Wkrótce po odbiorze zadania mistrz piekarski opuścił na zawsze Stolp i wyjechał do Wrocławia.

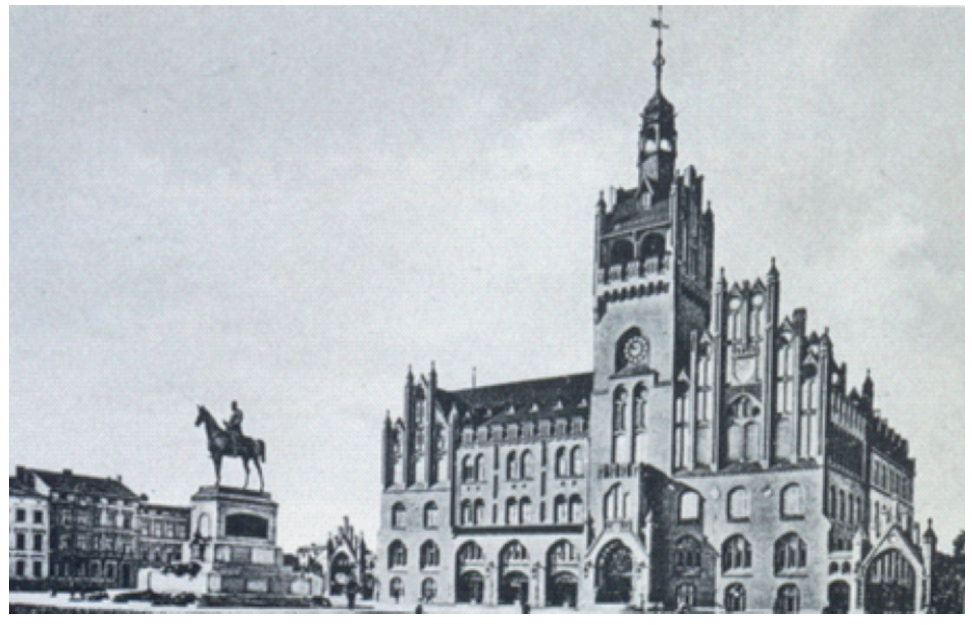

Ryc. 1. Pomnik cesarza Wilhelma I na koniu Źródło: pocztówka ze zbiorów Muzeum Pomorza Środkowego w Słupsku

${ }^{8} \mathrm{Z}$ początku Targ Wełniany był placem używanym tylko do celów targowych i nie był wybrukowany, a tylko ubity (Foltyn 2021).

${ }^{9}$ Najpierw pracował do września $1854 \mathrm{r}$. Wówczas zgłosił powierzoną mu pracę do odbioru. Niestety, po tych pierwszych pomiarach wykonanych przez mierniczego o nazwisku Schulz, zleconych mu przez ówczesnego burmistrza Wahla, Komisja Magistracka nie odebrała zadania i uznała, że jest ono „nie do końca wykonane” (do uzgodnionej wysokości wypełnienia zabrakło kilku centymetrów). W konsekwencji Wienandt został zmuszony do uzupełnienia brakującej części oszacowanego „wypełnienia” (Foltyn 2021). 
Uroczyste odsłonięcie pomnika mającego uwiecznić niemieckiego cesarza nastąpiło 5 września 1910 roku, a dokonał go jego wnuk, Wilhelm II, który razem z żoną uczestniczył w bardzo odświętnie obchodzonym jubileuszu. Granitowy Denkmal, przedstawiający odlaną w brązie postać cesarza siedzącego na koniu, był dziełem berlińskiego rzeźbiarza Johannesa Boese. Pomnik ten zastąpił istniejący wcześniej w tym miejscu, wzniesiony ku pamięci ofiar wojny francusko-pruskiej, Denkmal z roku 1875 (Schulz, Wolter 1984: 94-97; Szpilewski 2003) - ryc. 2.

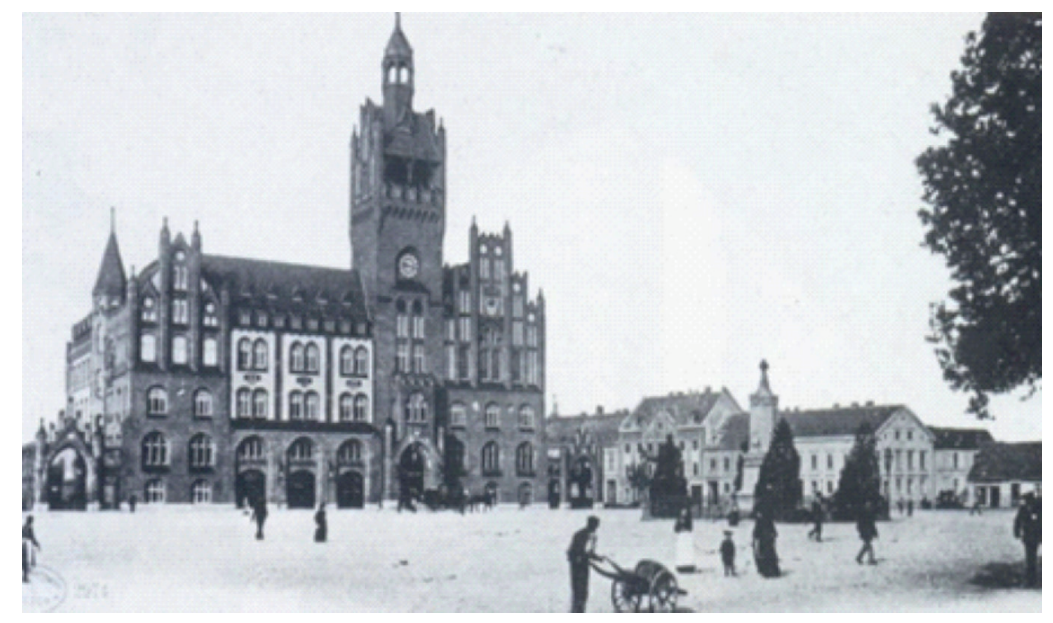

Ryc. 2. Pomnik przed ratuszem (1875) wzniesiony ku pamięci ofiar wojny francusko-pruskiej (1870-71)

Źródło: pocztówka ze zbiorów Muzeum Pomorza Środkowego w Słupsku

Pomnik dedykowany żołnierzom niemieckim, poległym w latach 1870-71, został przeniesiony na cmentarz komunalny, gdzie istniał jeszcze po II wojnie światowej, czego dowodzą zachowane fotografie nowych mieszkańców miasta, osiedlających się w Słupsku należącym do tzw. ziem odzyskanych. Trudno orzec, czy osoby uwiecznione na zdjęciach zdawały sobie sprawę, na tle jakiego pomnika się fotografują (ryc. 3).

Przedwojenne pomniki Słupska, umiejscawiane w miejscach ważnych dla układu przestrzennego miasta, charakteryzowały się tradycyjną, dziewiętnastowieczną formą i były dziełami znanych rzeźbiarzy niemieckich. Najważniejsze z nich powstały na początku XX wieku. Już w 1901 roku u zbiegu Bismarckplatz (aktualnie ul. Henryka Sienkiewicza) i Banhofstrasse (aktualnie ul. Wojska Polskiego) postawiono Denkmal Otto von Bismarcka (Schulz, Wolter 1984: 102). Pomnik kanclerza był dziełem Meyera-Steglizta (ryc. 4). 

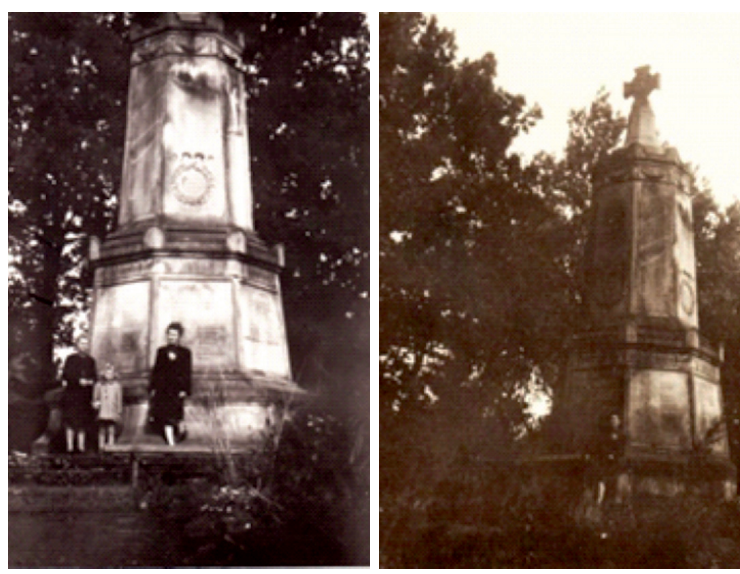

Ryc. 3. Pomnik pamięci ofiar wojny francusko-pruskiej przeniesiony na cmentarz komunalny (1945)

Źródło: zbiory Muzeum Pomorza Środkowego w Słupsku

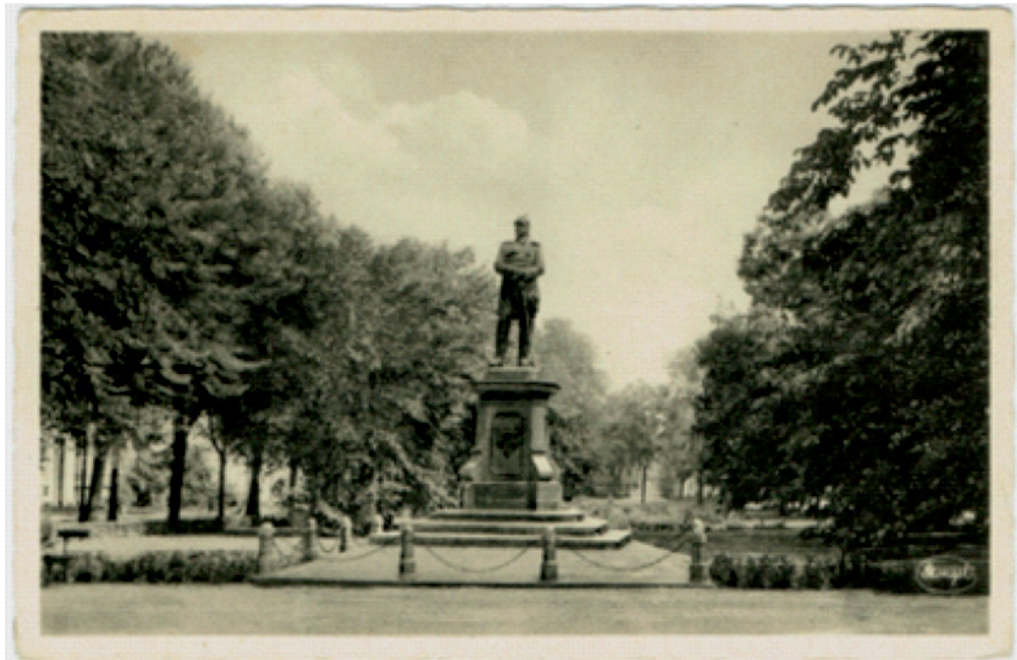

Ryc. 4. Słupskie planty - pomnik kanclerza Otto von Bismarcka u zbiegu Bismarckplatz i Banhofstrasse (1901)

Źródło: pocztówka ze zbiorów Muzeum Pomorza Środkowego w Słupsku

Siedem lat później, z okazji 150. rocznicy istnienia pułku huzarów w Słupsku, w roku 1908 na Marktplazt (aktualnie plac nosi nazwę Stary Rynek) stanął wykonany z piaskowca posąg marszałka Gebharda von Blüchera (Schulz, Wolter 1984: 16-20)-ryc. 5 i 6.

Autorem pomnika dowódcy pułku słupskich huzarów był Cuno von Uechtritz-Steinkirch (Schulz, Wolter 1984: 86-87); huzarom słupskim został natomiast poświęcony Denkmal wykonany przez Frantza Dorrenbacha w 1925 roku, wzniesiony na Schraderplatz (obecnie Plac Powstańców Warszawy) - ryc. 7. 

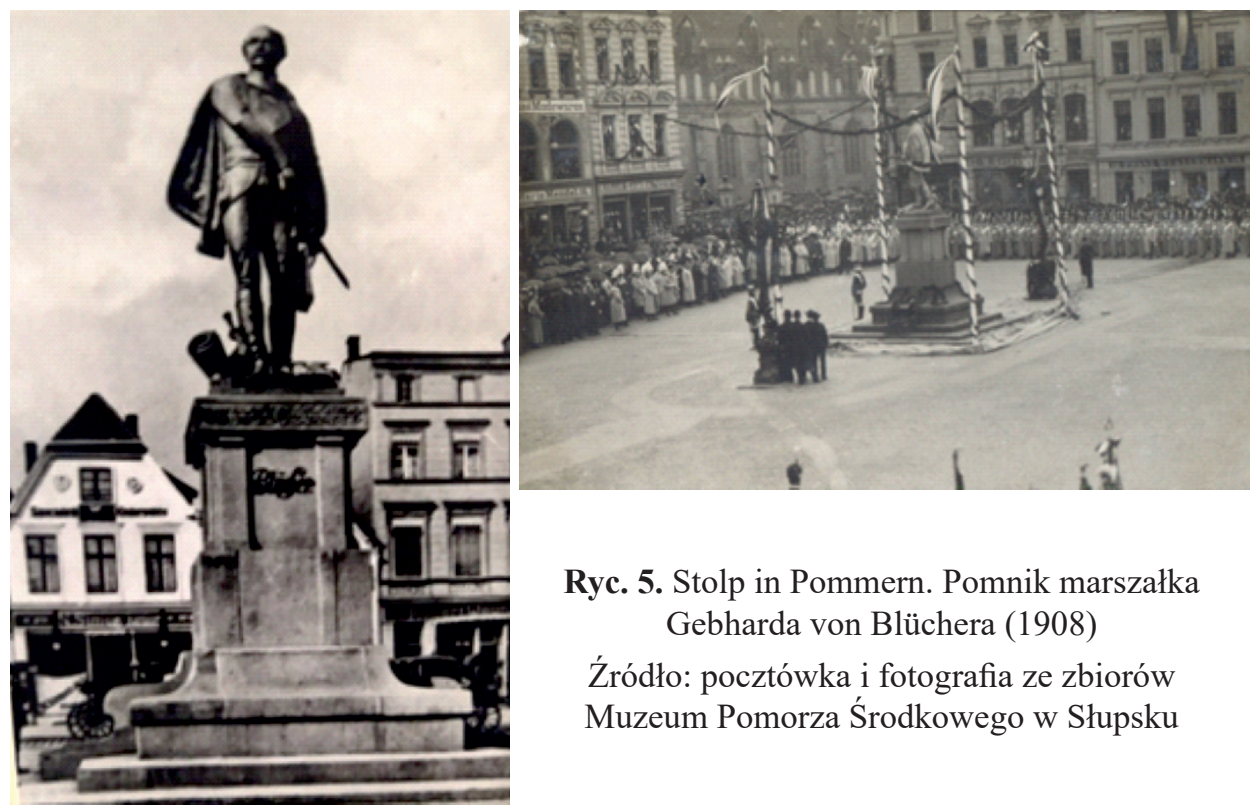

Ryc. 5. Stolp in Pommern. Pomnik marszałka Gebharda von Blüchera (1908)

Źródło: pocztówka i fotografia ze zbiorów Muzeum Pomorza Środkowego w Słupsku
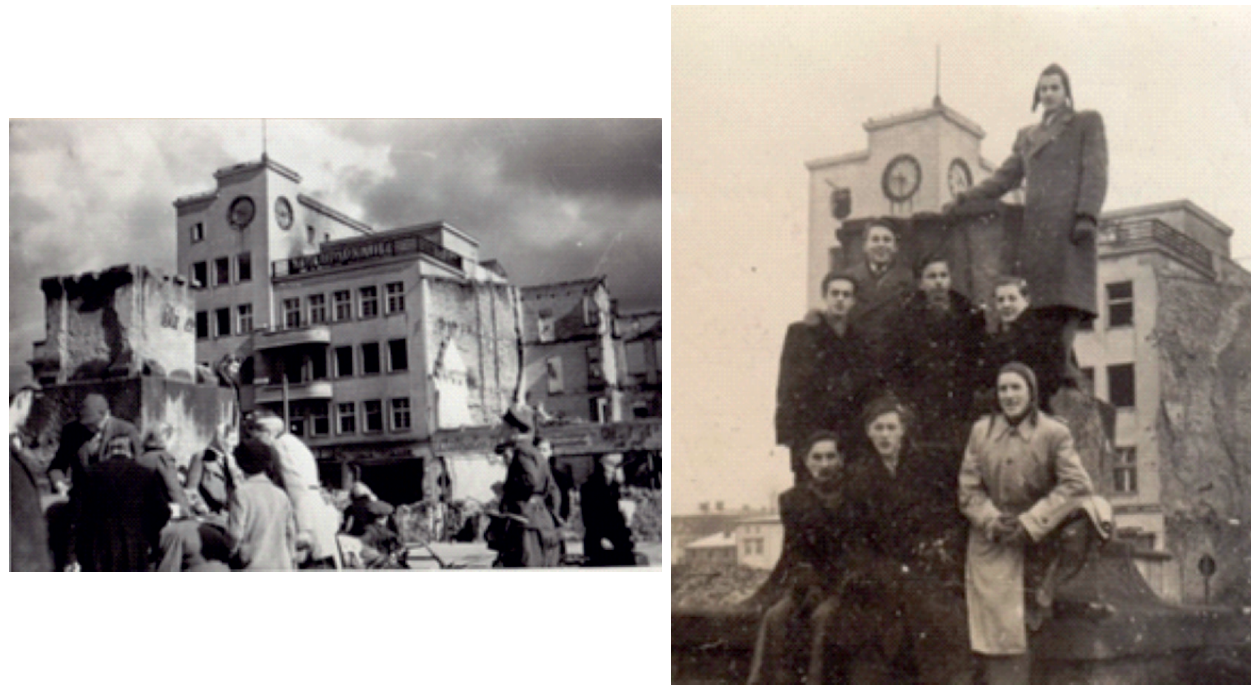

Ryc. 6. Stary Rynek po II wojnie światowej. Cokół po pomniku von Blüchera jako sceneria pamiątkowych zdjęć

Źródło: zbiory Muzeum Pomorza Środkowego w Słupsku 


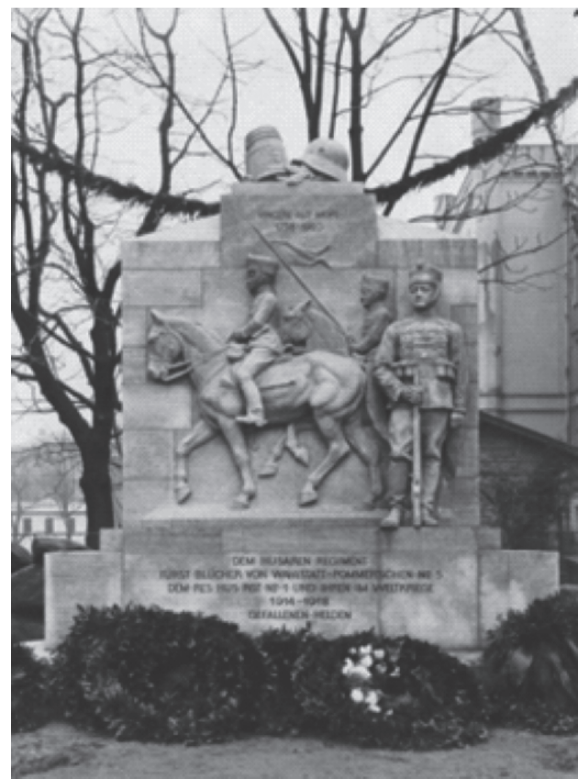

Ryc. 7. Pomnik huzarów słupskich (1925)

Źródło: zbiory Muzeum Pomorza Środkowego w Słupsku

Niestety, przedwojenne Denkmale Słupska uległy dewastacji - niektóre w trakcie działań wojennych, jak np. pomnik Blüchera czy Wilhelma I, inne w wyniku planowej, powojennej reorganizacji przestrzennej „odzyskanego" miasta. Ich smutny los nie jest zjawiskiem niezwykłym. Powszechnie znaną praktyką - zwłaszcza związaną z konfliktami militarnymi - jest niszczenie przez zwycięzców wszelkich dowodów istnienia tych, którzy wcześniej zasiedlali dany teren. Tego typu „niechciane dobra kultury" w literaturze naukowej funkcjonują jako dissonant heritage (trudne dziedzictwo) i dotyczą wytworów kultury materialnej stworzonych na jakimś obszarze przez grupę dominującą, które przez ich następców (pojawiających się wskutek jakiejśs transformacji społeczno-historycznej lub demograficznej) są odbierane negatywnie; najczęściej ze względu na nasycenie obcymi treściami i symbolami, co prowadzi do ich społecznego odrzucenia lub całkowitej dewastacji (Tunbridge, Ashworth 1996; Graham, Ashworth, Tunbridge 2000; Gutowska 2003).

W Słupsku sytuacja bezpośrednio związana z takim „trudnym dziedzictwem” była jeszcze bardziej skomplikowana, ponieważ nowi osadnicy, którzy przybyli do miasta po II wojnie światowej pochodzili - jak zasygnalizowano już na wstępie niniejszego studium - z różnych stron II Rzeczypospolitej, w tym z Kresów Wschodnich: Ukrainy i Wileńszczyzny. Poza nimi w Słupsku osiedlali się również rdzenni mieszkańcy Pomorza. W swoim kulturowym bagażu dźwigali i przynieśli do miasta nad Słupią różnorodne zwyczaje i wartości. Stworzyli swoisty tygiel kulturowy, jednak mimo tego zróżnicowania zastane dziedzictwo, tzw. ,poniemieckie" było dla nich niełatwe do oswojenia i zaanektowania, ponieważ budziło skojarzenia z krzywdami wyrządzonymi narodowi polskiemu przez 
hitlerowskiego agresora. W konsekwencji skutkowało to „odniemczaniem”, „polonizacją” lub „repolonizacją” Ziem Zachodnich. Procesy swoistego zawłaszczania były tym silniejsze, im bogatsze i zauważalne to dziedzictwo było - dotyczyło to zwłaszcza urządzeń technicznych, zabudowań, rozwiązań komunikacyjnych, czy osiedli fabrycznych (Mazur 2000: 813-850).

Niemcy w większości opuścili miasto Gryfitów i tylko niektórzy z nich po latach zdecydowali się na powrót. Wybitnym przykładem w tym kontekście jest Isabel Sellheim (o której wspomniałam wyżej) - osoba bardzo zaangażowana w działania prowadzące do międzynarodowego pojednania, która do miasta opuszczonego w 1945 roku powróciła na stałe i - na jej własne życzenie - 25 sierpnia 2018 roku została pochowana na Cmentarzu Komunalnym w Słupsku w rodzinnym grobie. Kobieta ta jest znakiem czasów najnowszych. Jednak powojenne losy miasta nad Słupią zapisały się w historii niestety innymi zgłoskami. Dzieje te można oglądać przez pryzmat zmieniających się pomników, które uznaje się za modelowe obiekty wizualizujące symboliczne panowanie na jakimś terytorium - dlatego właśnie na miejscu jednych stawia się inne i zaznacza w ten sposób nową rzeczywistość społeczną, polityczną i tożsamościową (Nijakowski 2006: 66 i nast.). Jak pisze Małgorzata Praczyk, wszelkie monumenty nie są ani neutralnymi, ani pasywnymi obiektami przestrzeni publicznej:

W wyjątkowych, granicznych momentach historii wywołują i kanalizują silne ludzkie emocje włączając się w główny nurt wydarzeń. [...] aktywnie uczestniczą w życiu miast i ich mieszkańców także na co dzień, gdy pozornie niezauważane, dopełniają przestrzeń, która nas otacza. Przy nich umawiamy spotkania, z nimi robimy sobie zdjęcia, niekiedy wdrapujemy się na nie, [...].wygląda na to, że są one towarzyszami naszego codziennego życia, choć wydawałoby się, że pamiętamy o nich tylko przy okazji wydarzeń czy postaci, którym są poświęcone (Praczyk 2015: 11).

Znakiem powojennej rzeczywistości państwa polskiego, które znalazło się pod kuratelą ZSRR, był w Słupsku strzelisty obelisk z tablicą, na której umieszczono napis w języku rosyjskim sławiący żołnierzy Armii Czerwonej, którzy 8 marca szturmem zdobyli miasto ${ }^{10}$. Obelisk został wzniesiony już wiosną 1945 roku

${ }^{10}$ Niezależnie od obelisku z gwiazdą usytuowanego przed ratuszem, z inicjatywy Słupskiego Oddziału Przyjaźni Polsko-Radzieckiej w roku 1949 na Cmentarzu Komunalnym wzniesiono pomnik poświęcony żołnierzom Armii Czerwonej w miejscu ich zbiorowych mogił; istnieje on do dziś. Ten i inne pomniki istniejące w przestrzeni miasta po 1945 roku, wznoszone zgodnie z obowiązującą polityką (a przy okazji służące również propagandzie PRL) opisał szczegółowo Zygmunt Szultka (Szultka 1988). Badacz skoncentrował się jednak wyłącznie na obiektach dedykowanych pamięci narodowej. W swoim opracowaniu skrupulatnie zanalizował materiały archiwalne, które ich dotyczą oraz na uwarunkowaniach historycznych ich powstania. Pominął pomniki nie związane z tym tematem (np. kompozytorów). Nie odniósł się również do okresu przedwojennego, który 
z inicjatywy radzieckiej komendantury wojskowej stacjonującej wówczas w mieście (ryc. 8a). Monument ten miał żelbetową konstrukcję, na której były umocowane białe i czerwone płyty marmuru, a zwieńczała go czerwona gwiazda. Pomnik poświęcony radzieckim żołnierzom usytuowano na honorowym miejscu, które przed wojną Niemcy przeznaczyli dla Wilhelma I. Postument nie odznaczał się szczególnymi walorami artystycznymi - był przede wszystkim odzwierciedleniem ówczesnej sytuacji politycznej w Polsce, a na Placu Zwycięstwa w Słupsku stał do 24 lipca 1962 roku (Szultka 1988: 17). Rozbiórka obelisku okazała się dużym wyzwaniem. Próby zdemontowania pomnika trwały przez trzy dni. Czołg, który wykorzystywano do demontażu, nie podołał zadaniu - przyczepiona do pomnika lina zerwała się, a w ciągnącym ją czołgu zatarł się silnik. Ostatecznie podjęto decyzję o podłożeniu ładunków wybuchowych. Jednak detonacja nie przyniosła zamierzonego skutku - w wyniku eksplozji z okien pobliskich domów wyleciały szyby, a pomnik stał nadal. Usunięto go dopiero po podcięciu szyn konstrukcyjnych (ryc. 8b). Na jego miejscu wzniesiono granitowy obelisk z postacią żołnierza autorstwa Krystyny Trzeciak ze Szczecina. Tym razem został on poświęcony żołnierzom polskim i radzieckim. Uroczyste odsłonięcie pomnika nastąpiło 1 września 1962 roku. Prawą ścianę pomnika zdobi 5 tablic - płaskorzeźb o humanitarnej treści - na pierwszej, najwyżej usytuowanej są wizerunki zwycięskich żołnierzy rzucających zdobyte sztandary hitlerowskie; druga wizualizuje radość matek i żon z odniesionego zwycięstwa, końca wojny i powrotu żołnierzy do domów; trzecia, na której jest gołąb, symbolizuje pokój; czwarta jest wyrazem hołdu dla tych, którzy poświęcili dla innych własne życie; piąta jest symbolem braterstwa. Monument istnieje do dnia dzisiejszego, ale po modernizacjach związanych z przemianami ustrojowymi PRL i RP współcześnie nosi nazwę Pomnika Żołnierzy Polskich (ryc. 9, fot. 1).

W 1945 roku, czyli w tym samym, w którym został wzniesiony obelisk sławiący żołnierzy radzieckich, powstał w Słupsku pomnik upamiętniający powstańców warszawskich. Był to pierwszy tego typu obiekt wzniesiony w powojennej Polsce. Powstał w wyniku spontanicznej inicjatywy grupy Polaków, w tym przybyłych z Warszawy, którzy osiedlili się w mieście nad Słupią, a na przełomie listopada i grudnia 1945 roku stanowili około 10\%. Według źródeł historycznych grupa warszawska - na tle ówczesnej mozaiki demograficznej miasta - wyróżniała się wyższym od przeciętnego wykształceniem oraz dużą aktywnością i przedsiębiorczością. Predyspozycje te sprzyjały społecznym inicjatywom. Prawdopodobnie dzięki nim Pomnik Powstańców Warszawskich, który usytuowano na miejscu Pomnika Słupskich Huzarów, odsłonięto już 15 września 1946 roku (ryc. 10). Co prawda jego pierwotna, dość prowizoryczna forma okazała się nietrwała i szybko uległa

w historii miasta nad Słupią wydaje się być nie tylko ważny, ale i inspirujący do poszukiwania i odkrywania w krajobrazie kulturowym miasta nie tylko tego co dzieli, ale i tego co intryguje. 

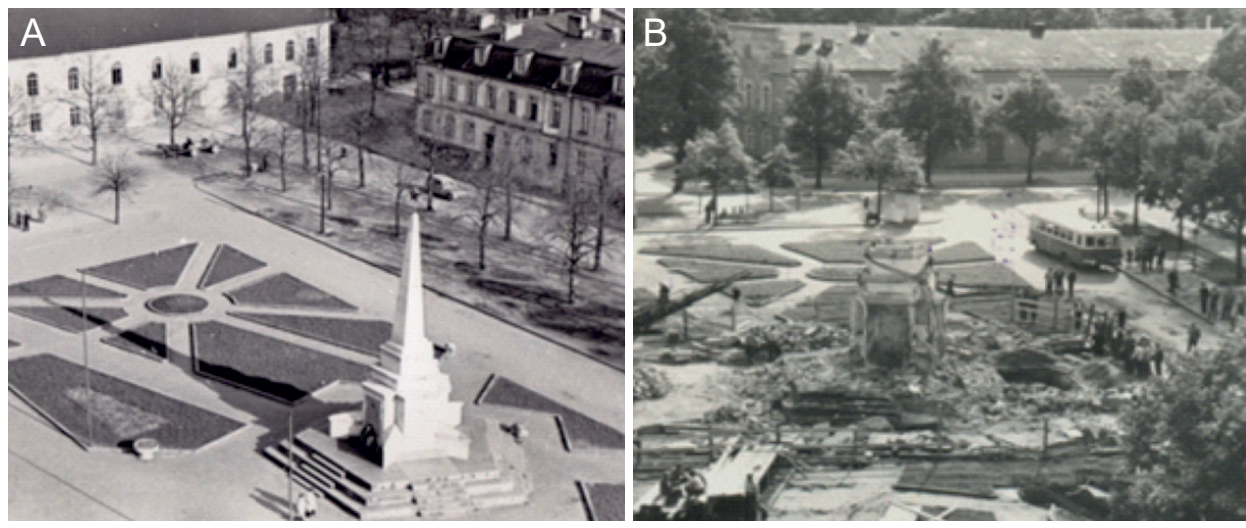

Ryc. 8. Obelisk sławiący Armię Czerwoną na placu Zwycięstwa w czasie prosperity (A) i w trakcie jego rozbiórki (B)

Źródło: zbiory Muzeum Pomorza Środkowego w Słupsku

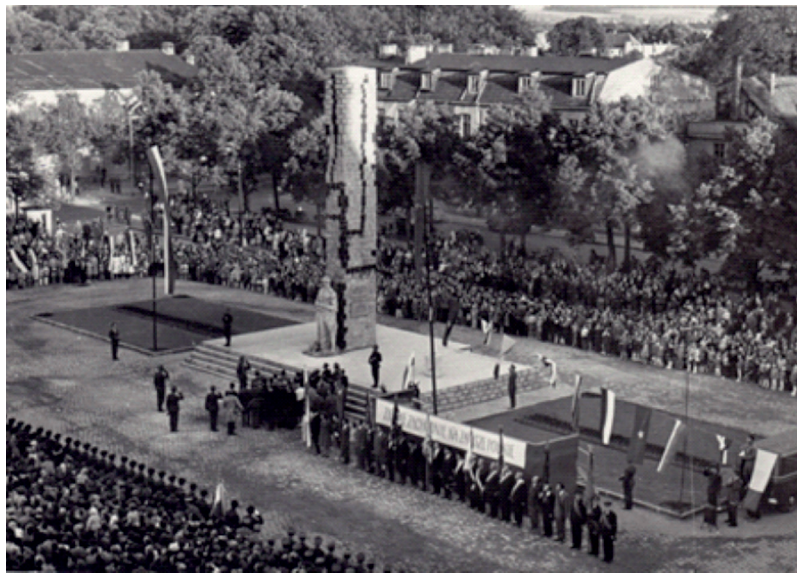

Ryc. 9. Obelisk na placu Zwycięstwa sławiący żołnierzy polskich i radzieckich

Źródło: zbiory MPŚ w Słupsku

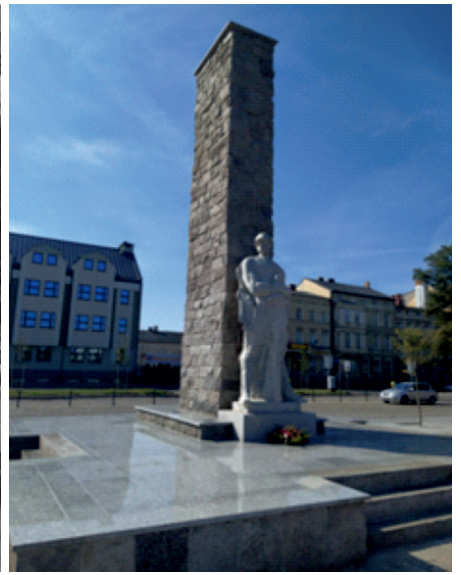

Fot. 1. Pomnik Żołnierzy

Polskich (stan obecny)

Źródło: fot. K. Krawiec-Złotkowska

zniszczeniu, niemniej fakt ten nie ujmuje mu znaczenia. W konsekwencji z inicjatywy ówczesnego naczelnika oddziału Urzędu Informacji i Propagandy, Stanisława Wysockiego, w maju 1946 roku Zarząd Miejski uchwalił, że w miejscu dotychczasowego pomnika - zbudowanego z desek ustawionych na cokole, symbolizujących mur, przed którym Niemcy dokonywali w stolicy publicznych egzekucji - stanie „coś naprawdę godnego”. W celu realizacji projektu został powołany społeczny Komitet Budowy Pomnika z E. Ładą-Cybulskim na czele. Środki 
zgromadzone przez ów komitet, pochodzące głównie z darów mieszkających wówczas w Słupsku Polaków, umożliwiły bardzo szybką budowę tego nowego „naprawdę godnego” obiektu (Szultka 1988: 23-31). Dokładnie rok po odsłonie pierwszego, 15 września 1946 r., nastąpiło odsłonięcie pomnika w formie, która istnieje do dzisiaj. Zaprojektował go warszawski rzeźbiarz Jan Małeta. Pomnik przedstawia poległego w walce powstańca, który leży na postumencie z piaskowca. Tło stanowi ceglany, z wyrwami, pokryty kulami mur symbolizujący ruiny i zgliszcza Warszawy po upadku Powstania. U stóp mężczyzny klęczy płaczące dziecko (symbol niewinności), a nad jego głową unosi się orzeł (symbol męstwa i dumy). Powstaniec jedną rękę opiera na tarczy herbowej Warszawy, a w drugiej trzyma granat, który jest znakiem nierównej, ale ofiarnej, do ostatniej kropli krwi, walki z faszystowskim okupantem. Na cokole widnieje napis: Bohaterom Warszawy - Stupsk (fot. 2). W centralnej części muru - przypominającego ściany i mury budynków, przy których Niemcy dokonywali publicznych egzekucji - na tle płonącego placu Zamkowego w Warszawie znajduje się płaskorzeźba Ukrzyżowanego Chrystusa. Jest to dosyć wyjątkowe przedstawienie Pasji, ponieważ do Krzyża przybite są tylko nogi i lewa ręka, natomiast prawą dłonią Jezus zasłania Swoje oczy tak, jakby nie mógł znieść widoku ludzkiej tragedii. Dramat sceny pogłębia obraz ludzi płonących w ogniu i wołających o ratunek, których wzniesione ku górze dłonie widoczne są na wysokości nóg Odkupiciela. Warto w tym miejscu przypomnieć, że w 1974 roku zamiast figury przedstawiającej Ukrzyżowanego umieszczono na pomniku płaskorzeźbę słupskiego gryfa (ryc. 11). Niemniej był to tylko kilkuletni epizod i w 1982 roku Odkupiciel wrócił na swoje miejsce. Współcześnie przy pomniku odbywają się uroczystości związane z rocznicami powstania warszawskiego oraz upamiętniające zamordowanie polskich i radzieckich robotników przymusowych i jeńców wojennych ${ }^{11}$.

$\mathrm{Na}$ prawie niezmienionym cokole kanclerza zjednoczonych Niemiec, Otto von Bismarcka stanęła statua polskiego laureata nagrody Nobla z 1905 roku - Henryka Sienkiewicza. Pomnik powstał z okazji 650-lecia miasta obchodzonego w 1960 roku, a autorką jego projektu była Krystyna Trzeciak (ryc. 12, fot. 3).

Na postumencie pomnika widnieje napis: Henryk Sienkiewicz, Spoleczeństwu $w$ 650. rocznice Stupska, Rzemiosto Cechowe. Jest on związany z tym, że to

${ }^{11}$ Ofiarom tym - rozstrzelanym 7 marca 1945 r., czyli ostatniego dnia przed ustąpieniem wojsk hitlerowskich $\mathrm{z}$ miasta lub pomordowanym na terenie miasta $\mathrm{w}$ czasie II wojny światowej - poświęconych jest w Słupsku kilka pomników. Na uwagę zasługuje na pewno pomnik wzniesiony w 1974 r. na południowym krańcu miasta, w miejscu kaźni - Lasku Południowym (wówczas Waldkazter). Pomnik ma ciekawą formę kolistej brukowanej powierzchni ze zniczem i granitową tablicą na środku; wokół tablicy znajdują się 24 różnej wysokości i grubości obeliski z wyrytymi na nich trójkątnymi znakami z literą „P”. Jego autorem jest słupski artysta-plastyk Mirosław Jaruga (Szultka 1988: 35-41, 44-53). 


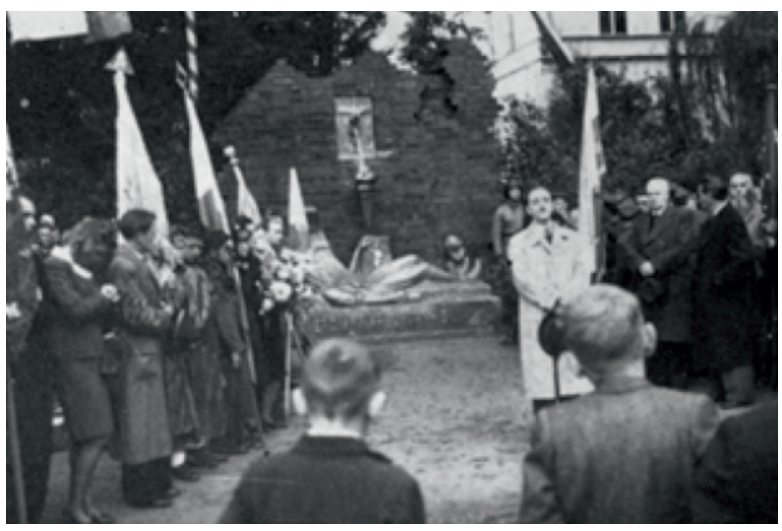

Ryc. 10. Odsłonięcie Pomnika Powstańców Warszawskich 15 września 1946 r. Źródło: zbiory Muzeum Pomorza Środkowego w Słupsku

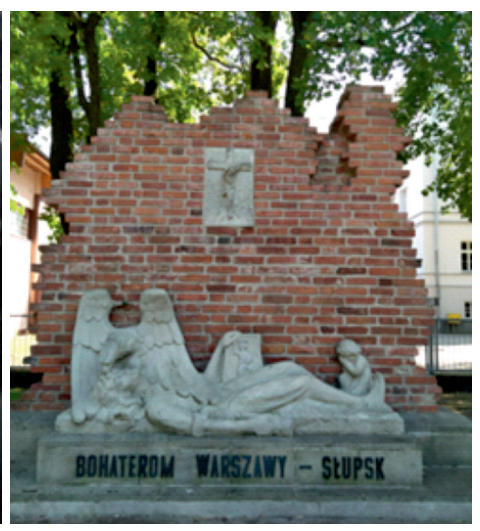

Fot. 2. Pomnik Powstańców Warszawskich (stan obecny) Źródło: fot. K. Krawiec-Złotkowska

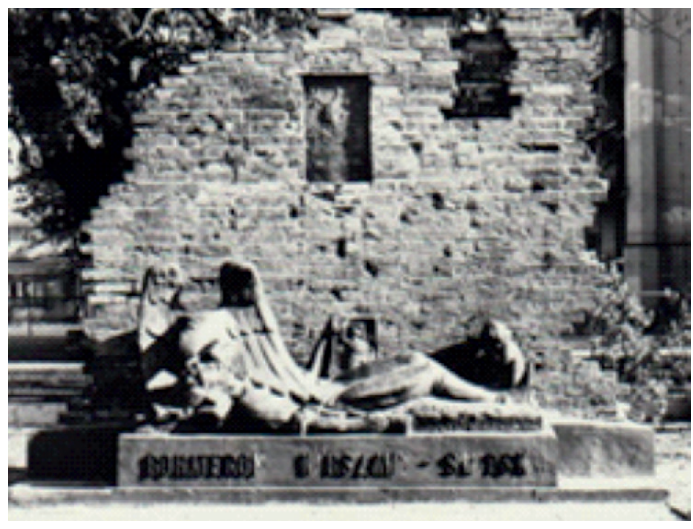

Ryc. 11. Wersja pomnika z płaskorzeźbą słupskiego gryfa Źródło: zbiory Muzeum Pomorza Środkowego w Słupsku

właśnie rzemieślnicy byli najbardziej zaangażowani w jego powstanie i uroczystości odsłonięcia, które było najważniejszym momentem w obchodach 650-lecia Słupska. Fakt ten dokonał się 17 lipca 1960 roku na reprezentacyjnej wówczas alei im. Generała Popławskiego; po postawieniu pomnika pisarza przemianowano ją na aleję Sienkiewicza. Ciekawostką może być fakt, że w chwili powstania pomnik miał barwę betonu; dopiero w 1996 roku został pokryty środkiem konserwującym imitującym metal.

Jubileusz 650-lecia grodu nad Słupią był nagłaśniany przez ówczesną władzę. W lokalnej gazecie z 15 lipca 1960 roku zatytułowanej „Kronika Słupska” można odnaleźć informację, że jubileuszowe uroczystości były organizowane przede wszystkim przez rzemieślników. W dniu poprzedzającym obchody odbyła się ich narada, a na odsłonięcie pomnika zjechali się rzemieślnicy z całego województwa - przyjechało ok. 1200 osób. W prasie z tamtego okresu można 


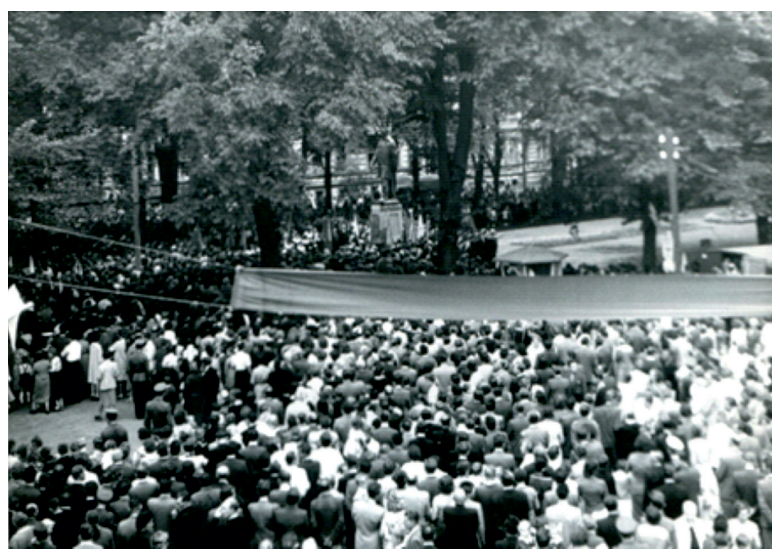

Ryc. 12. Odsłonięcie pomnika Henryka Sienkiewicza

Źródło: zbiory Muzeum Pomorza Środkowego w Słupsku

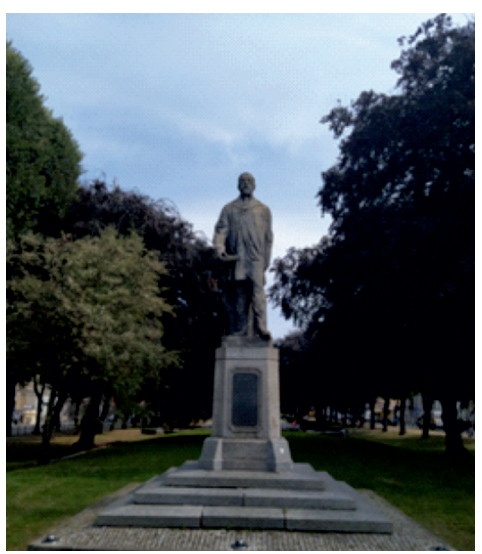

Fot. 3. Słupskie planty współcześnie. Pomnik H. Sienkiewicza (1960) Źródło: fot. K. Krawiec-Złotkowska

znaleźć dużo informacji o przebiegu uroczystości związanych z odsłonięciem monumentu, niestety nic o nim samym ${ }^{12}$. W „Kronice Słupskiej” z 20 lipca jest jedynie krótka wzmianka, że po odsłonięciu pomnika w alejkach pobliskiego parku dziennikarze spotkali autorkę rzeźby, która „miała w oczach łzy”.

Miejsce na Starym Rynku, na którym przed wojną stał posąg marszałka Gebharda von Blüchera, nie doczekało się ,,godnego" następcy ${ }^{13}$. Tuż po wojnie próbowano ten teren zagospodarować i wzniesiono na nim klomb z kompozycją kwiatową. Następnie pojawiła się tam mała fontanna, ale ją też zlikwidowano, a po ostatnich pracach archeologicznych teren wyrównano i nie ma na nim żadnego elementu dekoracyjnego. Trochę to smutne, że władze miasta nie mają pomysłu, jak ozdobić jeden z głównych miejskich placów, miejsce, w którym istniały dwa pierwsze słupskie ratusze (ryc. 13).

${ }^{12} \mathrm{Z}$ prasy dowiadujemy się, że w niedzielę 17 lipca 1960 r. uroczysty pochód rozpoczął się na Starym Rynku, skąd skierował się pod pomnik H. Sienkiewicza. Na czele na motocyklu jechał pilot z flagą państwową, a za nim na motorach jechali rzemieślnicy z Człuchowa. Za nimi szły dziewczęta ubrane w stroje regionalne, które niosły bukiety kwiatów. Następnie maszerowały poczty sztandarowe i starszyzna cechowa w tradycyjnych strojach rzemiosła. Dalej jechały wozy symbolizujące kilkanaście różnych rzemiosł; każdy z nich był przygotowany przez inny powiat, https://gp24.pl/sienkiewicz-w-swoim-parku/ar/4336865 (dostęp: 2.03.2021).

${ }^{13} \mathrm{Z}$ okresem II wojny światowej łączą się tematycznie również pomniki: Dzieciom Polskim zmarłym w Słupsku w latach 1939-1945 oraz Krzyż Katyński i Krzyż Wołyński, które znajdują się na starym cmentarzu (2006); krzyże ufundowało Społeczeństwo Słupska. 


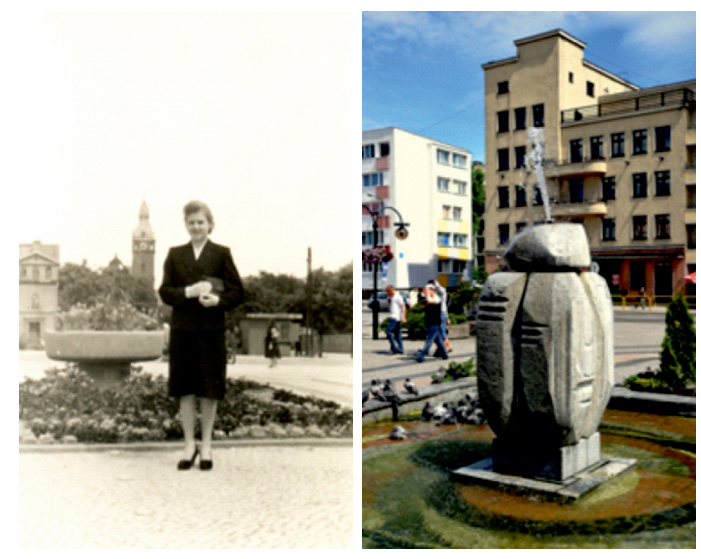

Ryc. 13. Stary Rynek po II wojnie

światowej po uprzątnięciu ruin i w nowych aranżacjach

Źródło: zbiory Muzeum Pomorza Środkowego w Słupsku

Snując refleksje o przedwojennych i powojennych pomnikach Słupska, nie można pominąć tego, który istniał przed II wojną światową i zachował się do czasów współczesnych. Stanowi on swoisty łącznik między okresem przed i powojennym. To pomnik Upokorzony (Der Gebeugte) z 1919 roku, który możemy oglądać na Skwerze Pierwszych Słupszczan przy ul. Starzyńskiego (wówczas Bachstrasse). Zachował się prawdopodobnie dlatego, że nie znajdował się na terenie miasta, lecz stał na opuszczonym i zniszczonym rodowym cmentarzu familii von Gamp-Massauen w Damnicy (przed wojną Hebron-Damnitz), miejscowości położonej niedaleko Słupska. Rzeźba została zakupiona przez Klarę Freiherr dla upamiętnienia jej męża Karla Freiherr von Gamp-Maussaunen zmarłego 13 września 1918 roku w Berlinie. Jej autorem był niemiecki rzeźbiarz Fritz Klimsch. Neoklasycystyczna figura z 1919 roku ${ }^{14}$ przedstawia nagiego mężczyznę w przyklęku i nawiązuje do Myśliciela - znanego dzieła francuskiego rzeźbiarza Augusta Rodina. Do Słupska została przeniesiona w 1972 roku, ponieważ istniało zagrożenie, że może zostać zdewastowana. Rzeźba wizualizuje człowieka zadumanego nad losem jego ojczyzny - Niemiec, które zostały upokorzone po I wojnie światowej traktatem w Wersalu. Upokorzony jako wybitne dzieło został wpisany do rejestru zabytków (Schulz, Wolter 1984: 79).

Sygnalizowane w tytule niniejszego szkicu ,wędrówki” przedwojennych i powojennych pomników najpełniej chyba oddaje lapidarium stworzone na starym

${ }^{14}$ Dzieło Fritza Klimscha nie jest jedynym przedwojennym pomnikiem, jaki zachował się w Słupsku. Poza nim na Cmentarzu Komunalnym przy ul. Kaszubskiej można podziwiać odrestaurowaną w 2005 r. neorenesansową rzeźbę nagrobną w formie aediculi, która ozdabia grobowiec rodziny Kaufmann. Rzeźba ta nie zmieniła swojego historycznego położenia, znajduje się in situ jej pierwotnego usytuowania. Ona również, podobnie jak Upokorzony została wprowadzona do rejestru zabytków. Przedstawia pogrążoną w smutku kobietę, stojącą w niszy, pomiędzy jońskimi kolumnami, https://ustka.travel/a320-gr-oacuteb-rodziny-kauffmann-w-slupsku.html (dostęp: 3.03.2021). 


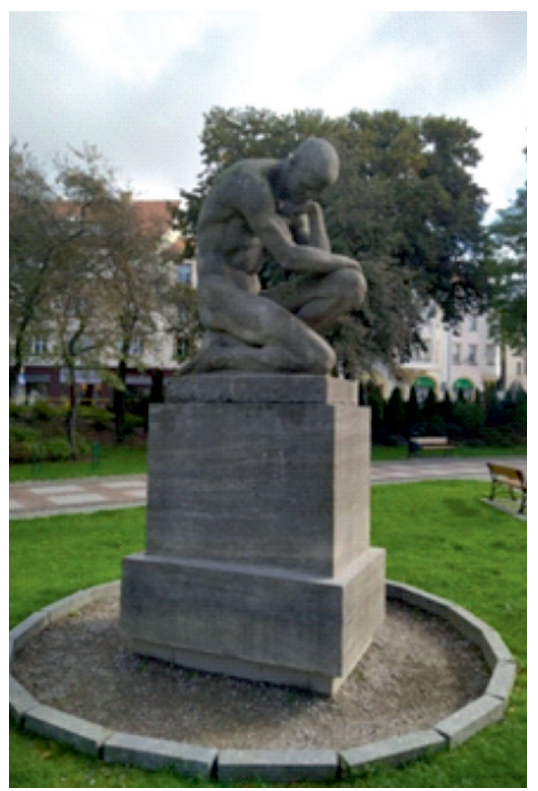

Fot. 4. Pomnik Upokorzony (Der Gebeugte) z 1919 r. na Skwerze Pierwszych Słupszczan przy ul. Starzyńskiego

Źródło: fot. K. Krawiec-Złotkowska

cmentarzu w Słupsku (fot. 5). Kamienie nagrobne i płyty z inskrypcjami i epitafiami w języku niemieckim niezbicie dokumentują ślady przedwojennych mieszkańców miasta - tych, których obecność i pamięć o nich po 1945 roku próbowano zacierać $\mathrm{w}$ złudnym przekonaniu, że w ten sposób zostaną ostatecznie ugruntowane polskie prawa do tzw. Ziem Odzyskanych ${ }^{15}$. Jednak barbarzyńską dewastacją materialnych pamiątek trudno zniszczyć pamięć. Gdy po II wojnie światowej wygasła obawa przed utratą Pomorza, a stosunki polsko-niemieckie uległy normalizacji, zaczęto tworzyć lapidaria i wznosić pomniki przypominające dawnych mieszkańców miast i wsi. Niemniej, zanim to nastąpiło, musiały dorosnąć nowe pokolenia ludzi, których stosunek do cmentarzy i przechowywanej na nich pamięci uległ radykalnej przemianie. Ludzi, którzy w Niemcach zobaczyli takich samych jak oni, chodzących tymi samymi ulicami, chowanych na tym samym cmentarzu, na którym oni dzisiaj grzebią swoich bliskich (Machura 2011: 5; Machura 2021). Dzięki nim - i dzięki takim osobom jak wspomniana już wcześniej Isabel Sellheim - podziały zostały zniwelowane, stworzono pomost zrozumienia, a nagrobki, które mogłyby ulec całkowitemu zniszczeniu, zawędrowały w nowe miejsce. Pamięć została ocalona.

${ }^{15}$ E. Wiązowski (2006: 36) zauważa, że ,dewastacja poniemieckich nekropolii spowodowana była tuż po wojnie chęcią odwetu za krzywdy wyrządzone przez hitlerowców. [...] Największe zniszczenia były jednak następstwem prowadzonej przez władze centralne i terenowe okresu PRL ideologicznej polityki likwidowania wszystkiego, co kojarzyło się z niemiecką historia tych ziem, kapitalizmem i zachodem Europy". 

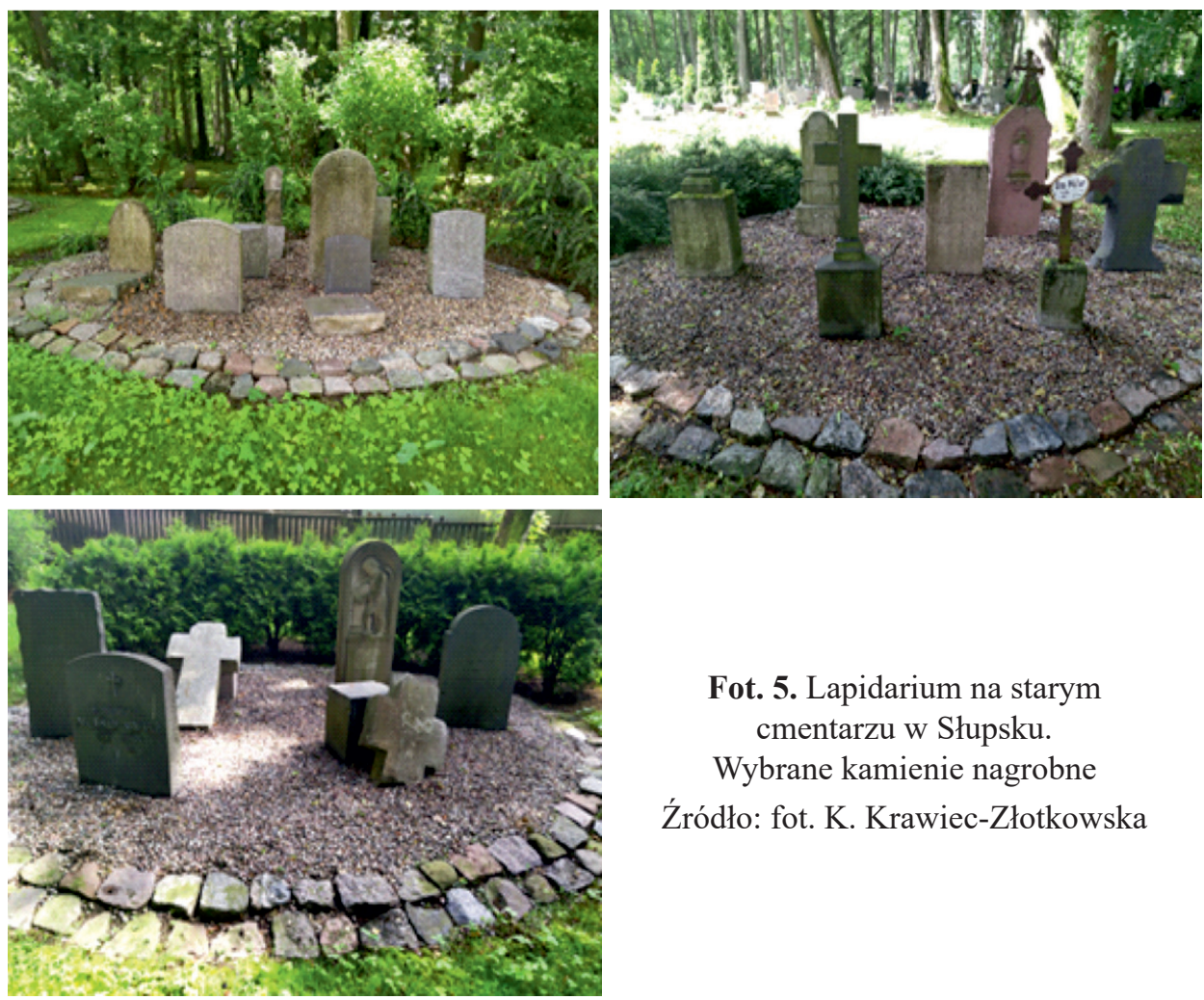

Fot. 5. Lapidarium na starym cmentarzu w Słupsku.

Wybrane kamienie nagrobne

Źródło: fot. K. Krawiec-Złotkowska

Ostatnią kwestią, która wymaga odnotowania w kontekście „wędrujących” pomników, a do takich bezwzględnie należy zaliczyć miejsca pamięci, czyli cmentarze, są macewy ocalone z żydowskiego kirkutu. Historia cmentarza słupskiej gminy żydowskiej sięga roku $1815^{16}$. Został on założony przy Totenweg (obecnie ul. Kaszubska). Przy wejściu na kirkut w latach 1907-1908 wzniesiono okazały dom przedpogrzebowy zaprojektowany przez E. Rosera. Jest to murowany budynek na planie prostokąta, z charakterystycznymi ryzalitami o półkolistym zwieńczeniu, który istnieje do dzisiaj. W czasie II wojny światowej cmentarz ten został zdewastowany. W 1941 roku w wyniku nacisku władz nazistowskich gmina żydowska musiała go sprzedać - część działki, na której był położony, przyłączono wówczas do sąsiadującego z tym terenem cmentarza miejskiego, a część została wydzierżawiona ogrodnikowi Albertowi Reetzowi z przeznaczeniem na gospodarstwo ogrodnicze. Niektóre nagrobki Reetz wykorzystał na fundamenty szklarni. Po 1945 roku opuszczony kirkut nikogo nie interesował i ulegał dalszej degradacji. Mimo tragicznego stanu wciąż można było na nim odnaleźć

${ }^{16} \mathrm{https}$ ///sztetl.org.pl/pl/miejscowosci/s/38-slupsk/114-cmentarze/32615-cmentarz-zydowski-w-slupsku (dostęp: 5.03.2021). 
macewy. W latach 70. XX wieku władze miasta postanowiły usunąć istniejące jeszcze wówczas nagrobki, a kirkut włączyć do Cmentarza Komunalnego. Przed rozpoczęciem reorganizacji terenu, słupski historyk Warcisław Machura wykonał serię zdjęć, dzięki którym udokumentował zachowane nagrobki. Wówczas też w dawnym domu przedpogrzebowym powstała Pracownia Konserwacji Zabytków. W 1994 roku na cmentarzu postawiono pomnik, który kształtem przypomina macewę o półkolistym zwieńczeniu (fot. 6).

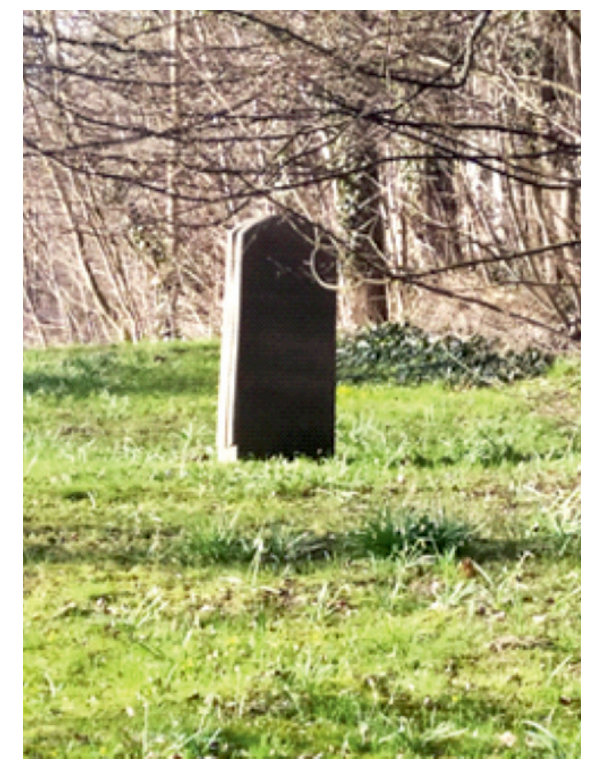

Fot. 6. Pomnik o kształcie macewy w miejscu dawnego kirkutu. Na pomniku znajduje się napis $\mathrm{w}$ językach hebrajskim i polskim o treści: Pamięci Żydów, których prochy spoczywaja w tej ziemi. Mieszkańcy $i$ władze miasta Stupska. 1994

Źródło: fot. K. Krawiec-Złotkowska

Nieliczne fragmenty odnalezionych żydowskich nagrobków zabezpieczono w dawnym domu przedpogrzebowym (Bielawski 2021), który 9 lipca 2005 roku został przekształcony w Izbę Pamięci Słupszczan. Natomiast aleja biegnąca wzdłuż ogrodzenia cmentarza w 2009 roku otrzymała nazwę ostatniego rabina Słupska, dra Maxa Josepha.

\section{Podsumowanie}

Los, jaki spotkał pomniki wznoszone przez Niemców w celu uhonorowania ich bohaterów lub zdarzeń, jest znakiem czasu i potwierdza przemiany ustrojowe i polityczne, jakie nastąpiły po II wojnie światowej. Taki sam status możemy przypisać pomnikom powojennym, które też ulegały różnym transformacjom. Natomiast inny wymiar zyskały pomniki pamięci, czyli miejsca pochówku przedwojennych mieszkańców miasta. Ocalone fragmenty macew, które zgromadzono i ochroniono przed całkowitym zniszczeniem, czy też małe lapidarium z niemieckimi płytami grobowymi to ślady ludzi, którzy żyli w grodzie nad Słupią 
i budowali przedwojenną społeczność. I chociaż zmieniły one swoją pierwotną lokalizację, to nie zmieniły statusu pro memoria. Niestety, nawet w ostatnich latach, gdy pojawiły się tendencje do szukania porozumienia i pojednania między różnymi nacjami, dochodzi do zjawisk wręcz barbarzyńskich. Przykładem mogą być zabytkowe grobowce znanych niemieckich rodzin szlacheckich z XVIII wieku - von Puttkamer, von Ziztewitz i Kaufmann, które zostały zniszczone w 2016 roku podczas budowy kolumbarium ${ }^{17}$. Z szeregu, w którym się znajdowały, ocalał tylko czarny postument poświęcony zmarłym Niemcom, mieszkańcom ziemi słupskiej, usytuowany na miejscu grobowca rodziny Westphal. Pomnik powstał w 1997 roku z inicjatywy Heimatkreise Stadt Stolp und Landkreis Stolp.

W przeszłości na postumencie znajdował się rzeźbiony krucyfiks, który został umieszczony w kaplicy cmentarnej; aktualnie na pomniku jest umieszczony werset biblijny, a na ścianie za nim umieszczono krzyż i dwie okolicznościowe tablice. Ów „wędrujący” krucyfiks, podobnie jak zmieniające swą lokalizację macewy oraz płyty z niemieckich nagrobków, w kontekście omawianej problematyki można interpretować jako pewnego rodzaju znaki uniwersalne, symbolizujące nie tylko zmianę, ale i przemianę - znaki, które przez samą swą obecność powinny skłaniać do refleksji nad przeszłością i wzbudzać poczucie tak trwania, jak i przemijania i które mogą stymulować poczucie więzi i budzić szacunek dla spuścizny odziedziczonej po tych, którzy w grodzie nad Słupią byli przed nami.

\section{Literatura}

Assmann A., 2013, Między pamięciq a historiq. Antologia, red. M. Saryusz-Wolska, Wydawnictwo Uniwersytetu Warszawskiego, Warszawa.

Assorodobraj-Kula N., 1963, Żywa historia, „Studia Socjologiczne”, 2.

Casey E.S., 1997, The fate of place. A philosophical history, University of California Press, Berkeley.

Chwedoruk R., 2018, Polityka historyczna, Wydawnictwo Naukowe PWN, Warszawa.

Erll A., 2020, Kultura pamięci. Wprowadzenie, przeł. A. Teperek, posł. i red. naukowa M. Saryusz-Wolska, Wydawnictwo Uniwersytetu Warszawskiego, Warszawa.

Foltyn R., 2021, Historia shupskich ratuszy, [w:] Krawiec-Złotkowska K. (red.), Rzeczpospolita domów, t. VI: Domy wiedzy i sztuki, Wydawnictwo Naukowe Akademii Pomorskiej w Słupsku, Słupsk (w redakcji).

Graham B., Ashworth G.J., Tunbridge J.E., 2000, A Geography of Heritage. Power, Culture and Economy, Londyn.

${ }^{17}$ https://m.radiogdansk.pl/wiadomosci/item/54416-zniszczone-xviii-wieczne-nagrobki-niemieckich-rodzin-szlacheckich-w-slupsku/ (dostęp: 3.03.2021). 
Gutowska K., 2003, Niechciane dobra kultury: chronić czy niszczyć?, [w:] Gutowska K. (red.), Dziedzictwo kulturowe - konteksty odpowiedzialności, Warszawa.

Heidegger M., 1954/2007, Odczyty i rozprawy, thum. J. Mizera, Wydawnictwo Aletheia, Warszawa.

Kobyliński Z., 2011, Czym jest, komu jest potrzebne i do kogo należy dziedzictwo kulturowe?, „Mazowsze. Studia Regionalne”.

Les Lieux de mémoire, 1984, red. P. Nora, t. 1, Paris.

Lewicka M., 2012, Psychologia miejsca, Wydawnictwo Naukowe Scholar, Warszawa.

Machura W., 2011, Dawne miejsca pamięci o żotnierzach na terenie powiatu stupskiego, Słupsk.

Mazur Z., 2000, Dziedzictwo wyłączone, podzielone, wspólne, [w:] Mazur Z. (red.), Wspólne dziedzictwo? Ze studiów nad stosunkiem do spuścizny kulturowej na Ziemiach Zachodnich i Pólnocnych, Poznań.

Nijakowski L., 2006, Domeny symboliczne. Konflikty narodowe i etniczne $w$ wymiarze symbolicznym, Warszawa.

Praczyk M., 2015, Materia pomnika. Studium porównawcze na przykładzie monumentów w Poznaniu i Strasburgu w XIX i XX wieku, Wydawnictwo Uniwersytetu A. Mickiewicza w Poznaniu, Poznań.

Pruszyński J., 2001, Dziedzictwo kultury Polski, jego straty i ochrona prawna, t. 1, Kraków.

Romanow Z., 2001, Zajęcie Stupska przez Armię Czerwona w 1945 roku, [w:] Łysiak W. (red.), Życie dawnych Pomorzan, Materiały z konferencji, Bytów 20-21 października 2000, Bytów-Poznań.

Schulz F., Wolter B., 1984, Stolp. Bilder aus dem Leben der Stadt von 1860 bis 1984, Bonn-Bad Godesberg.

Skóra W., 2021, Stupsk w 1945 r. Miasto Niemców, czerwonoarmistów i Polaków, [w:] Skóra W., Teterycz-Puzio A. (red.), Stupsk i ziemia stupska od średniowiecza do współczesności, Słupsk.

Słownik terminologiczny sztuk pięknych, 1997, red. K. Kubalska-Sułkiewicz, Wydawnictwo Naukowe PWN, Warszawa.

Szpilewski S., 2003, Pomniki i tablice pamiątkowe w Stupsku, Słupsk.

Szpociński A., 1983, Kanon historyczny, „Studia Socjologiczne”, 4.

Szpociński A., 1989, Przemiany obrazu przeszłości Polski. Analiza stuchowisk historycznych dla szkót podstawowych 1951-1984, Instytut Socjologii, Uniwersytet Warszawski, Warszawa.

Szpociński A., 2008, Miejsca pamięci (lieux de memoire), „Teksty Drugie”, 4(112).

Szultka Z., 1988, Pomniki i miejsca pamięci narodowej w Stupsku, Słupsk.

Trojański P., 2018, Miejsca pamięci w przestrzeni publicznej, [w:] Wojdon J. (red.), Historia $w$ przestrzeni publicznej, Wydawnictwo Naukowe PWN, Warszawa. 
Tunbridge J.E., Ashworth G.J., 1996, Dissonant Heritage. The Management of the Past as a Resourse in Conflict, Chichester.

Wiązowski E., 2006, Pomorskie cmentarze, „Powiat Słupski. Biuletyn Informacyjny”, 5-6.

\title{
Netografia
}

Bielawski K., http://cmentarze-zydowskie.pl/slupsk.htm (dostęp: 5.03.2021). http://www.regionslupski.pl/art-pomniki-w-slupsku.html (dostęp: 3.02.2021). https://gp24.pl/sienkiewicz-w-swoim-parku/ar/4336865 (dostęp: 2.03.2021). https://m.radiogdansk.pl/wiadomosci/item/54416-zniszczone-xviii-wieczne-nagrobki-niemieckich-rodzin-szlacheckich-w-slupsku/ (dostęp: 3.03.2021). https://sztetl.org.pl/pl/miejscowosci/s/38-slupsk/114-cmentarze/32615-cmentarz-zydowski-w-slupsku (dostęp: 5.03.2021).

https://ustka.travel/a320-gr-oacuteb-rodziny-kauffmann-w-slupsku.html (dostęp: 3.03.2021).

Machura W., Stupskie nagrobki, http://epigrafika.slupsk.pl/histirua-nagrobkami-pisana (dostęp: 3.03.2021).

\section{Wandering monuments in the space of Slupsk (before and after World War II)}

\begin{abstract}
The chapter presents monuments (denkmals) existing in Slupsk before World War II and monuments, which replaced them after 1945. Attention was also paid to pre-war objects, which changed their original location after the war (e.g. the memorial to the victims of the Franco-Prussian war, the sculpture Humiliated, fragments of German tombstones and Jewish matzevot). On the example of monuments, there is presented an outline of the post-war historical policy applied to the existing cultural heritage of the Western and Northern Territories. A manifestation of this policy was destroying the signs of a foreign culture or ignoring it and changing semantics. It was noticed that the cultural shift made after the transformation of 1989 and the abolition of censorship in 1990 in Poland, played an important role in the treatment of foreign heritage. Monuments in Slupsk are presented in the context of the theory of places of remembrance, culture of remembrance, historical politics, history in public space and the existing "difficult heritage". Their fate in the city "with exchanged blood" reveals a strategy of rejecting or assimilating foreign heritage, and at the same time prompts reflection on the past and the future.
\end{abstract}

Keywords: Slupsk, monument, theory of places of remembrance, historical policy, difficult heritage.

Dr hab. Krystyna Krawiec-Złotkowska, prof. AP

Akademia Pomorska w Słupsku

Instytut Filologii

e-mail: krystyna.krawiec-zlotkowska@apsl.edu.pl

https://orcid.org/0000-0003-0128-3148 